Annals of Warsaw University of Life Sciences - SGGW

Land Reclamation No 42 (1), 2010: 139-148

(Ann. Warsaw Univ. of Life Sci. - SGGW, Land Reclam. 42 (1), 2010)

\title{
Sediment transport and water quality in Máchovo Lake (Czech Republic)
}

\author{
TOMAS DOSTAL, JOSEF KRASA, KAREL VRANA, MARTIN DOCKAL, \\ PETR KOUDELKA, VACLAV DAVID, ADAM VOKURKA \\ Department of Irrigation, Drainage and Landscape Engineering, Czech Technical University in Prague
}

\begin{abstract}
Sediment transport and water quality in Máchovo Lake (Czech Republic). Máchovo Lake is a historical reservoir founded by Czech King Charles IV. in 14th century. Located in northern part of central Bohemia it has been widely used for recreation purposes for many decades (or even centuries). Its catchments (ca $100 \mathrm{sq} \mathrm{km}$ ) consist of intensively used agricultural land (ca $25 \%$ of area) and of large forested area under nature protection. Several other lakes (ponds) are chained on the two reservoir's inlets. Irrespective of its great recreation potential Máchovo Lake is one of the Bohemian lakes known for its problems with eutrophication and water quality. The project was set up to point out sources of nutrients and to search for proper solutions. Sediment loads in every lake within the catchments were measured and sampled in order to quantify the nutrients and other pollution. Point and non point sources of phosphorus and other nutrients were searched. Sediment transport within catchments was modelled using WaTEM/SEDEM model. Interestingly, the water quality in the particular ponds varies significantly even though each one of several hundred years old ponds is heavily silted. Soil erosion protection measures within catchments were proposed altogether with flood protection measures in the stream valleys and waste water treatment facilities in surrounding villages. Setting up water quality sampling devices in selected stream profiles was tested and designed. The continual proper management should lead to water quality improvement.
\end{abstract}

Key words: sediment loads, phosphorus, soil erosion, source of pollution.

\section{INTRODUCTION AND MOTIVATION}

Máchovo Lake (originally named "Large pond") is a man made reservoir founded by king Charles IV. in 1366 at Robecsky brook. Original purpose of the reservoir was obviously the fish production. The area was originally a wet valley and a swamp so the pond was efficiently designed here.

Later on, the attractive locality in between Czech Central Mountains and romantic Czech Eden regions became an important tourist hot-spot. Recently Máchovo Lake and its surroundings has become a centre of tourism of a large region. Recreation and related services form the core of the economy of the region.

In the last ca 30 years the water quality in the lake have rapidly worsened. The main contributor is a huge eutrophication caused by both point and non-point phosphorus sources in the catchments. Nowadays every year the summer season is characterized by water flower upraise accompanied by poisoned blue-green algae occurrence.

Already several times the situation lead to prohibition of bathing during summer months and recreational potential of the 
region dropped down significantly. Such early season ending has vast social and economical impact for the region (Vrana et al. 2008).

The algaecide chemicals were applied to the water or sediment surface, to reduce water blossoming and phosphorus remobilization from the sediment and to solve acute situation. The situation has been nevertheless found as unsustainable in long term period.

Therefore, State Agency for Nature and Landscape Protection initiated a study on identifying the pollution sources in the catchments quantifying their impact and proposing concept of measures. The study was conducted using various data sources, catchment monitoring and data based on original research (Vrana et al. 2009). The presented paper presents shortly the study.

\section{MATERIALS AND METHODS}

\section{Study area}

The area of interest covers catchments of Robecsky stream ended by Máchovo Lake outlet (dam). The watershed area is $100.1 \mathrm{~km}^{2}$. The Máchovo Lake has $2.61 \mathrm{~km}^{2}$ area and average depth of $2.2 \mathrm{~m}$. Its retention capacity is $5.255 .750 \mathrm{~m}^{3}$. Máchovo Lake has two main tributaries - Robecsky stream and Brehynsky stream. At the Robecsky stream (the main tributary) there is a cascade three smaller ponds - Cepelsky, Poselsky and Paterin$\mathrm{ka}$. At the Brehynsky stream there is only one large Brehynsky pond - an ancient pond founded by the time or Máchovo Lake origination. The pond and its surroundings are natural protected area.

The whole area of interest is located about $90 \mathrm{~km}$ north of Prague in an area of great natural interest. Pond system is located in depression stretching from east to west. North and east of it extends the Czech chalk boards, second largest known reserve of high quality ground water and in terms of morphology, the sandstone cover shaped into a very attractive rock formations by erosion. From the geological point of view, the surface is mostly sandstone rock. The light sandy soils are affected by weathering. From the economic point of view, it is an area with minimal agricultural use, morphologically predominantly flat surface.

Partially it is covered by wetlands but predominantly there is a pine forest. To the south and west there are the Czech Central Mountains, an area of former active volcanoes. Geologically, this part consists of the volcanic rock of various ages. Its morphology is a relatively rugged and steep area with significant isolated volcanic cones. On the slopes and the foot there is very fertile agricultural land, which historically was and currently still is used intensively.

Brehynsky creek sub-basin is practically un-settled, while in the basin of Robecsky stream there is concentrated permanent settlement and recreational infrastructure, including recreational areas at banks of the Máchovo Lake.

In terms of nature conservation it is also very vulnerable area, because there are sites of both mentioned bioregions. The remains of the original wetland habitat, which occurred in the originally flat marshy basins, are most valuable here. There are also number of conflicts of interest, especially among intensive recreation, nature conservation, the interests of farmers and fishermen and local businesses. 


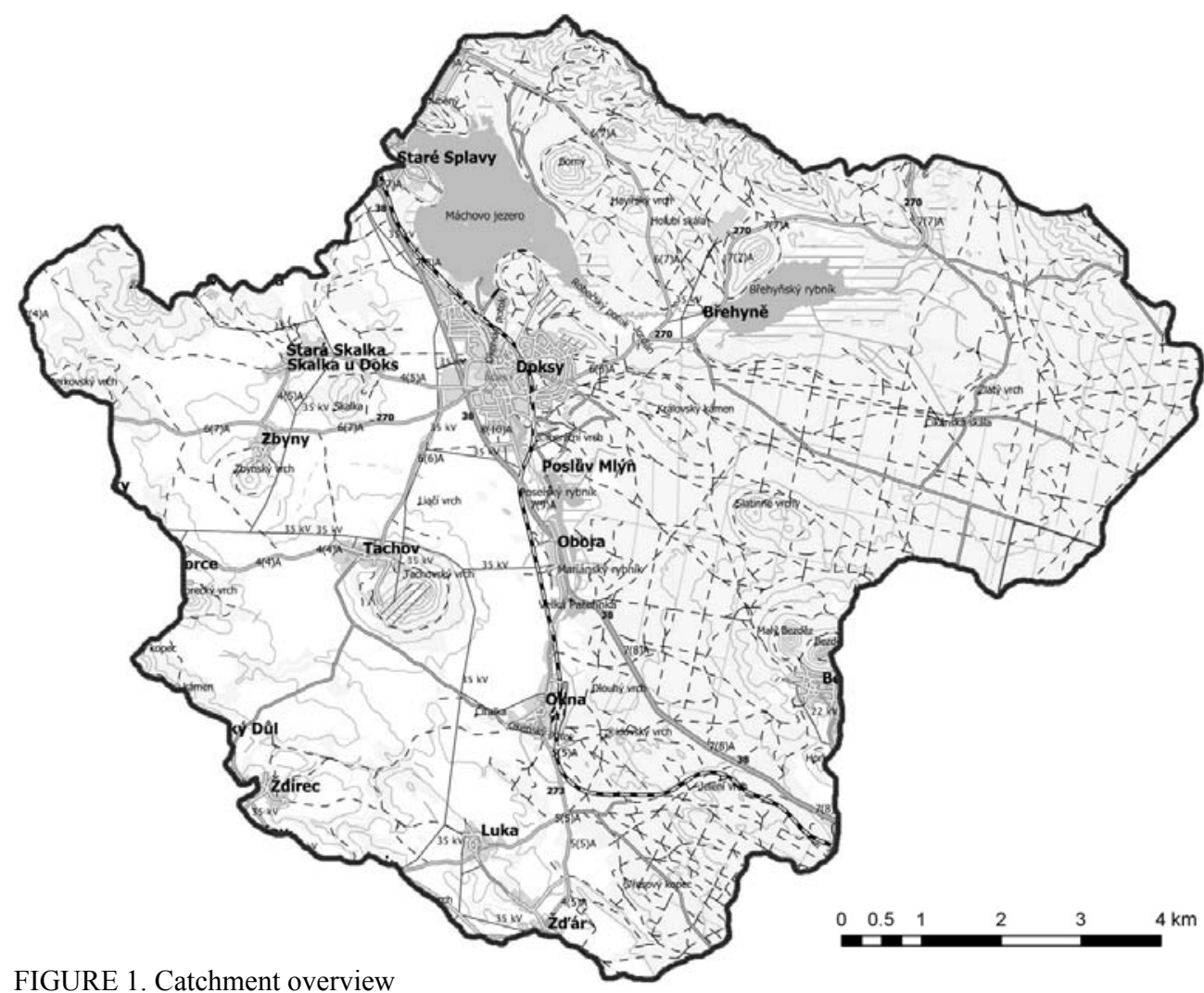

\section{Study structure}

The aim of this study was:

- Identification and quantification of point sources of pollution in the area of interest.

- Identification and quantification of diffuse sources of pollution

- Estimated share of various pollution sources in total balance.

- Development of hydrological model of the area.

- Drawing up the balance of transport of pollution from the catchment into the Máchovo Lake.

- Recommendations - effective measures to improve the state of eutrophication of the Máchovo Lake.

\section{Identification and quantification of point sources of pollution in the area of interest}

The main point sources of pollution were investigated in the following categories: permanent housing or recreation, the recreational facilities directly related to the Máchovo Lake, industrial companies and establishments and farms.

A detailed field survey was undertaken monitoring wastewater inlets into waterways, the state of these releases and the visible signs of pollution.

The evidence was concentrated concerning the status and operation of wastewater treatment in the larger settlements of the territory and the way of wastewa- 
ter disposal in recreational facilities. In addition, the results were put together on the monitoring of water quality and discharges in streams. The wastewater treatment plant under Doksy town was considered.

\section{Identification and quantification of diffuse sources of pollution}

As a non-point source of pollution in the area the erosion and transport processes were considered. Since the symposium is on sediment dynamics we will pay attention mainly to this point of the study.

Activities in this section can be divided into four parts:

- Determination of erosion vulnerability of agricultural land.

- Estimation of sediment transport into waterways and the hydrographic network.

- Determination of sediment deposition in individual reservoirs.

- Estimation of transported phosphorus as the main cause of eutrophication.

Determination of erosion risk on agricultural lands

The erosion risk was assessed using USLE (Wischmeier and Smith 1978) in combination with raster based GIS (Desmet and Govers 1996). The methodology was vastly published and has been successfully used for many studies. The assessment accuracy is influenced mainly by input data precision - here the 1:5000 soil maps and orthophotos were used and 1:10 000 topography maps for DTM and land cover derivation. The computation was conducted in 5 meters grid resolution.
Estimation of sediment transport into waterways

The Watem/SEDEM model was used (Van Rompaey et al. 2001; Verstraaten et al. 2002) for soil loss and sediment transport assessment. The model uses transport capacity (potential for a rill erosion) of every DTM cell to consider for erosion versus deposition at the catchments. Resulting are the maps of soil erosion and sediment deposition and also the values of sediment yield (transport into waterways) for every sub-catchment or every section of the stream. This way also sediment delivery ratio of every sub-catchments is defined. The soil erosion and sediment deposition map is presented at Figure 1.

The basic assumption was that no long-term sediment deposition occurs in channels of watercourses, but only in water tanks. Concerning the reservoir trapping efficiency it was estimated using Brune curves as adopted by Dendy (Dendy 1977) - depending on average outflow, reservoir capacity and sediment grain size distribution.

\section{Determination of sediment deposition in individual reservoirs}

The six important reservoirs in the catchments were surveyed and the sediment volumes were measured there. The sediment samples were taken to assess physical and chemical characteristics of the sediment (including of course enrichment by phosphorus).

The sediment volumes were measured using a 5 meters long calibrated probe (needle) from a small boat - this methodology is suitable for the purpose and reservoir type and was many times verified 
in other studies (Krasa et al. 2005). The aim was also to confirm or disprove the hypothesis that all deposited sediment does not come only from the erosion processes in the basin. In terms of sediment quality survey, during the measurement of each water tank we took 3 to 5 pooled samples of the sediment for the qualitative analysis.

The reservoirs capacities and sediment volumes are listed in Table 2.

\section{Estimation of transported phosphorus as the main cause of eutrophication}

Phosphorus in all its forms was clearly found to be the main limiting factor and cause of eutrophication of Máchovo Lake throughout the area of interest.

The preceding paragraphs have described ways of quantification. The most important sources are considered point (sewage effluent from residential and recreational buildings and recreational facilities, as well as agricultural buildings or small businesses and establishments) and non-point sources - especially sheet erosion from agricultural parts of the basin. Another potential source of phosphorus remobilization may be already stored in the pond sediment.

Quantification of pollution from point sources was based on operational data obtained at different treatment plants and water abstractions in four campaigns, as described in the paragraph describing the establishment of a mass balance model of the area.

Quantification of non-point sources of pollution was based on a total of three sources of information.

1. On data from the database agrochemi-cal testing of agricultural soils (a service of the Ministry of Agriculture to farmers).

2. Total of 10 disturbed soil samples were taken on the fields during the campaigns providing their chemical analysis to refine and validate data from agrochemical testing of agricultural soils.

3. Another source was then analyzing the samples of sediment taken directly from the individual reservoirs.

Concerning the phosphorus bound to sediment it was necessary to estimate the ratio of enrichment, based on soil particle size distribution and the trapping efficiency. The estimated values were validated by the results of the sediment samples analyses.

\section{Development of hydrological model of the area}

Rainfall-runoff model of the area was compiled using the basic hydrological balance relations. Before the study there have been only limited data on actual discharges: the daily water levels at Máchovo Lake and the reservoir's outflow characteristics.

In the higher parts of the basin there were no measured data available. Therefore, 8 specific profiles were founded for the study. These were four times measured during the season, defining flow rates, taking water samples for defining the pollution levels. The hydrological scheme of the catchments is presented at Figure 2.

\section{The balance of transport of pollution into the Máchovo Lake}

Balance was made based on data from a concentrated point and diffuse sources of pollution and from the streams moni- 
toring. Study monitoring system comprised of a total of 4 sampling campaigns that characterized the region of interest in various hydrological and operational status. In terms of operating conditions there were chosen positions of maximum and minimum load of the recreational area. The measured concentrations were subsequently quantified using the balance sheet and results of rainfall-runoff modelling.

\section{Recommendation the most effective measures to improve the state of the reservoir}

The aim of the study was to define the main sources of phosphorus, especially in the area of interest and to propose methods of their elimination. Solution was then based on mass balance and on identifying the most dangerous sites and the most important sources of phosphorus. These should be then addressed with priority.

Given the scope of this study the aim was to propose measures only generally. Detailed solutions will follow in particular designs of measures.

\section{RESULTS AND DISCUSSION}

Concerning the results mostly the analysis of erosion processes and sediment transport as a major non-point sources of pollution are presented. Other parts are mentioned only briefly in order to maintain the overall context of the study.

Summed results of sediment transport have been quantified for the outlets of individual sub-basins, which also corresponded to the water reservoirs' outlets in the area of interest (Fig. 2). The results of Watem/SEDEM modelling for each profile are listed in the table Table 1.

Parallel to this using GIS the sediment volume deposited in individual reservoirs was computed. The volumes based on sediment transport modelling do not correspond with measured volumes. In virtually all cases, the calculated volumes were significantly lower than the volumes measured. This suggests that not all sediment deposited in the tested reservoirs comes from erosion in the basin. Moreover, the results of field measurements clearly document that the actual mineral tank bottom is noticeably lower than the bottom during the construction of ponds. The extraction of all the sediment would leave deep lagoons with lower bottom then the reservoirs' outlets. This again confirms that the ponds were established in areas of natural wetlands and peatlands, and much of the sediment is significantly older and is of a natural and organic origin. Results of field measurement of

TABLE 1. The results of simulation model of sediment transport (Watem/SEDEM)

\begin{tabular}{|l|c|c|c|c|c|c|c|}
\hline Catchments ID & 011 & 012 & 013 & 014 & 015 & 016 & 017 \\
\hline Basin area $\left(\mathrm{km}^{2}\right)$ & 27.93 & 16.79 & 6.73 & 1.80 & 3.42 & 24.14 & 18.41 \\
\hline Agricultural area $\left(\mathrm{km}^{2}\right)$ & 12.72 & 11.25 & 0.36 & 1.05 & 1.20 & 1.36 & 2.04 \\
\hline Percentage of agricultural land & $46 \%$ & $67 \%$ & $5 \%$ & $58 \%$ & $35 \%$ & $6 \%$ & $11 \%$ \\
\hline Total soil loss (t/year) & 12590 & 8550 & 0 & 220 & 340 & 0 & 960 \\
\hline Total sediment deposition (t/year) & 12100 & 7700 & 0 & 190 & 300 & 0 & 920 \\
\hline Sediment transport (t/year) & 490 & 850 & 0 & 30 & 40 & 0 & 40 \\
\hline
\end{tabular}


the volume of deposited sediment are summarized in the Table 2.

The next step in terms of drawing up the balance of nutrients and phosphorus is the determination of phosphorus in agricultural soils in the area of interest. The starting material was a database of agrochemical testing of agricultural soils having 80 points (samples) in the study area. For verification and support there were collected 10 more disturbed soil samples that were analyzed also for the phosphorus content. Table 3 lists the contents of total $\mathrm{P}$ value, calculated on a $\mathrm{kg}$ of dry soil. According to agricultural standards used in the CR for the classification of agricultural land the soils in the study area lay within the category of soils with high to very high nutrient content.

For the values of phosphorus content in surface layers of sediment, in agricultural soil in the catchment and the results of particle size analysis, the enrichment ratio of approximately $1: 10$ (corresponding to the standard) was derived. Based on the estimated ratio of enrichment, the knowledge of the content of phosphorus in agricultural soils and sediment transport calculated it is possible to derive an overall balance of phosphorus transport in streams and reservoirs. The total balance - including the point sources loads and potentially active $\mathrm{P}$ deposits in ponds

TABLE 2. The sediment volumes and retention capacities of the reservoirs

\begin{tabular}{|l|c|c|c|c|c|c|}
\hline & $\begin{array}{c}\text { Břehyňský } \\
\text { pond }\end{array}$ & $\begin{array}{c}\text { Poselský } \\
\text { pond }\end{array}$ & $\begin{array}{c}\text { Čepelský } \\
\text { pond }\end{array}$ & $\begin{array}{c}\text { Máchovo } \\
\text { Lake }\end{array}$ & $\begin{array}{c}\text { Dokeská } \\
\text { bay }\end{array}$ & $\begin{array}{c}\text { Pateřinka } \\
\text { pond }\end{array}$ \\
\hline Area (ha) & 81.67 & 15.63 & 2.82 & 260.5 & 3.89 & 2.91 \\
\hline Measured points & 113 & 166 & 65 & 2200 & 30 & 10 \\
\hline $\begin{array}{l}\text { Actual storage capacity } \\
\text { (above sediment) }\left(\mathrm{m}^{3}\right)\end{array}$ & 1298400 & 230400 & 37000 & 5255750 & 41200 & 33600 \\
\hline Sediment volume $\left(\mathrm{m}^{3}\right)$ & 623100 & 109000 & 45500 & 936500 & 20300 & 19500 \\
\hline $\begin{array}{l}\text { Total accessible storage } \\
\text { capacity }\left(\mathrm{m}^{3}\right)\end{array}$ & 1921500 & 339400 & 82500 & 6192250 & 61500 & 53100 \\
\hline Recent average depth $(\mathrm{m})$ & 1.59 & 1.47 & 1.31 & 2.02 & 1.06 & 1.15 \\
\hline Average sediment depth $(\mathrm{m})$ & 0.76 & 0.70 & 1.61 & 0.36 & 0.52 & 0.67 \\
\hline Siltation (\%) & $32 \%$ & $32 \%$ & $55 \%$ & $15 \%$ & $33 \%$ & $37 \%$ \\
\hline
\end{tabular}

TABLE 3. Total phosphorus content, calculated on a kg of dry soil

\begin{tabular}{|l|c|c|c|c|c|}
\hline Sample No & 1 & 2 & 3 & 4 & 5 \\
\hline Date & 14.7 .2009 & 14.7 .2009 & 14.7 .2009 & 14.7 .2009 & 14.7 .2009 \\
\hline Time & $15: 30$ & $15: 32$ & $15: 34$ & $15: 36$ & $15: 38$ \\
\hline $\mathrm{P}(\mathrm{mg} / \mathrm{l})$ & 0.18 & 0.15 & 3.57 & 3.88 & 4.87 \\
\hline $\mathrm{P}(\mathrm{mg} / \mathrm{kg}$ dry $)$ & 1.8 & 1.5 & 35.7 & 38.8 & 48.7 \\
\hline Sample No & 6 & 7 & 8 & 9 & 10 \\
\hline Date & 14.7 .2009 & 14.7 .2009 & 14.7 .2009 & 14.7 .2009 & 14.7 .2009 \\
\hline Time & $15: 40$ & $15: 42$ & $15: 44$ & $15: 46$ & $15: 48$ \\
\hline $\mathrm{P}(\mathrm{mg} / \mathrm{l})$ & 1.85 & 1.17 & 2.50 & 2.56 & 2.00 \\
\hline $\mathrm{P}(\mathrm{mg} / \mathrm{kg}$ dry $)$ & 18.5 & 11.7 & 25 & 25.6 & 20 \\
\hline
\end{tabular}




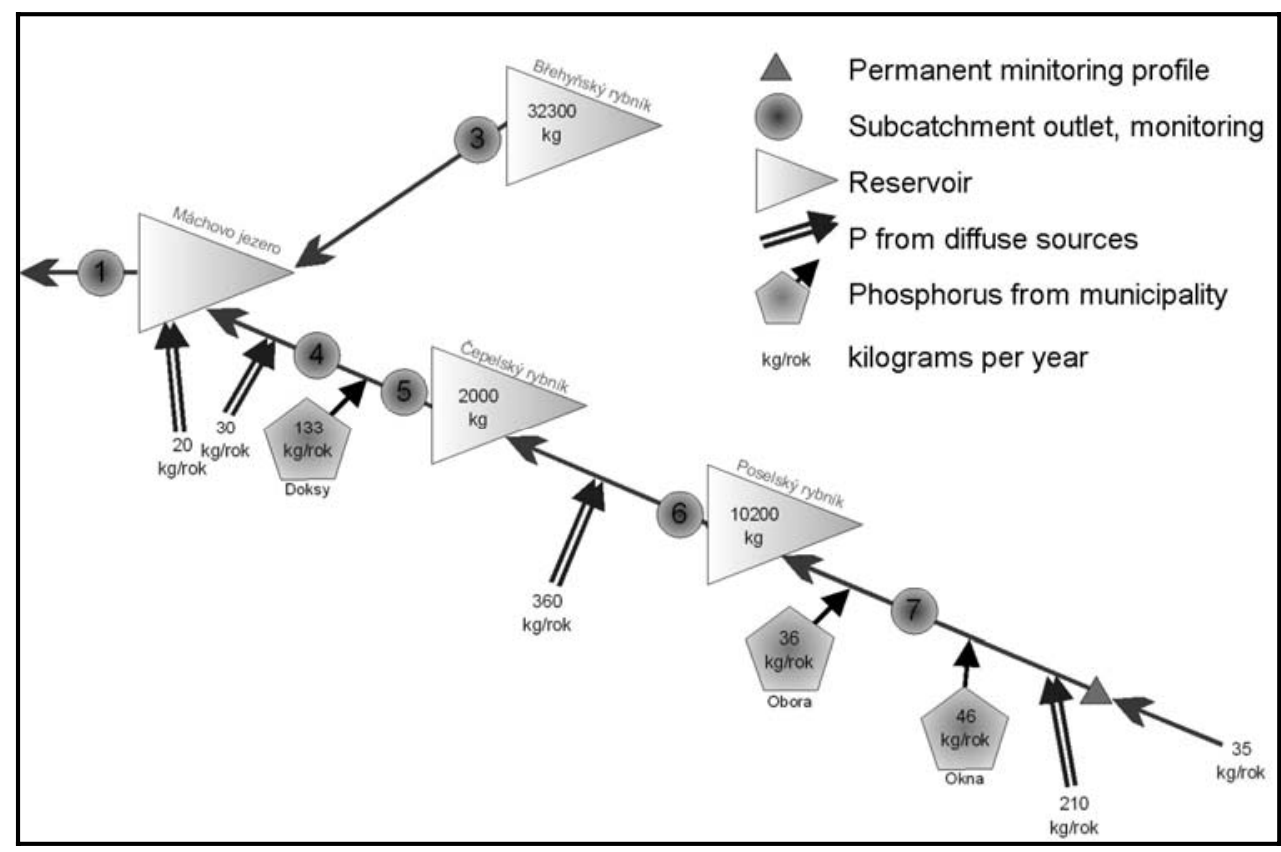

FIGURE 2. Overall balance of phosphorus transport in streams and reservoirs

- is illustrated in Figure 2. The phosphorus in the sediment deposited in reservoirs expected to be potentially active was the one in the surface sediment layer with a thickness of $10 \mathrm{~cm}$. The below deposited phosphorus was considered to be the unreachable, and so dropped out of balance.

Concerning other partial results, the following findings are important:

- Farms in the basin are (due to unclear Czech agricultural policies) slowed down and currently are not a major issue for the protection of water quality.

- P grants from sewage effluents of smaller communities in the basin are practically negligible, since municipalities are situated within a few miles from the Máchovo lake and are not connected to a permanent watercourse. The ground water may be polluted here, but with no clear link to the reservoir.

- The situation is different in the larger municipalities in close proximity of the Máchovo Lake. Leaks of the sewage water were observed during precipitation events.

- Overall balance, however, showed that non-point sources are (despite the high concentration of tourism) more important source of nutrients than point sources.

- For the precision of the proposals of protective measures continuous monitoring in the study area should be undertaken (monitoring both the hydrologic regime and the water quality to timely identify sources of pollution).

A fundamental finding is that the current background of the area, composed 
of forests, meadows and almost unused agricultural land still produces a total phosphorus concentration of around 0.1 to $0.2 \mathrm{mg} / \mathrm{l}$. These concentrations are in principle sufficient to start or maintain the eutrophication process (without further identified other sources of pollution). The fact documents the saturation of the landscape lasting long after the end of subsidies of nutrients.

\section{CONCLUSIONS}

Complex study, presented within the paper approved that agricultural land, used for intensive farming for a long period of time has been so much oversaturated by nutrients that even more than 15 years after its extensification it produces runoffs with high enough phosphorus content to feed eutrophication processes in water reservoirs.

Methods used for soil erosion risk and sediment transport assessment were again successfully validated and they proved their reliability regardless of even very substandard conditions.

A number of assumptions related to main pollution and nutrients sources within the catchment was shown as incorrect. Generally, the effect of point pollution sources has been overestimated, while the effect of non point pollution sources, namely soil erosion and sediment transport processes have been underestimated.

Sediment excavation from Máchovo Lake and most of other small reservoirs was approved as unnecessary and technically unrealistic. It will be necessary to continue in the future application of algaecide chemicals, like for instance PAX, to stabilize phosphor at bottom sediment in unavailable form. Maintenance of appropriate fish inhabitance within the reservoirs has been defined as very necessary condition.

There has been approved, that significant part of sediment identified within water reservoirs has organic historical origin. It shows, that it comes from peat, which naturally has been formed within local marshlands.

Generally, the study presented high potentials of complex assessment, based on structured approach (Dostal 2007). Such assessment can be applied even in conditions of high uncertainty, in case of detailed local surveys, measurements, sampling and reliable and suitable methods selection.

Acknowledgement: This paper has been worked out based on the results reached with support of the project "MSMT CR VZ CEZ MSM 6840770002 - Revitalization of water systems of the landscape and urban sites, significantly affected by anthropogenic changes" and research project "NAZV QI102A265 - Determination of effect of erosion phosphorus on eutrophication of endangered surface water bodies".

\section{REFERENCES}

DENDY F.E., CHAMPION W.A., 1978: Sediment Deposition in U.S. Reservoirs. MP-1362. U.S. Dept. Agr., Agr. Res. Serv.

DESMET P.J.J., GOVERS G., 1996: A GIS-procedure for automatically calculating the USLE LS-factor on topographically complex landscape units. Journal of Soil and Water Conservation, 51 (5): 427-433.

DOSTAL T., 2007: Strukturovaný př́stup k modelování procesů $\mathrm{v}$ krajině, habilitační práce, [Structured approach to modelling the landscape processes, habilitation] FSv ČVUT v Praze. 
DOSTÁL T., KRÁSA J., VRÁNA K., JAKUBÍKOVÁ A., DAVID V., ZANDLER D., 2006: Metody a způsoby predikce povrchového odtoku, erozních a transportních procesů $v$ krajině, [Methods of prediction of surface runoff, erosion and transport processes] zpráva projektu COST 1P04OC634.001, FSv ČVUT v Praze.

KRÁSA J., DOSTÁL T., VRÁNA K., VASKA J., VAN ROMPAEY A., 2005: Reservoirs' Siltation Measurements and Sediment Transport Assessment in the Czech Republic, the Vrchlice Catchment Study. CATENA., vol. 2-3, no 64, p. 348-362.

VRÁNA K., DAVID V., DOČKAL M., DOSTÁL T., KOUDELKA P., ET AL., 2008: Optimalizace stavu vodnich ekosystémů v povodi Robečského potoka I. [Optimalisation of water ecosystems stability in Robecsky stream, technical study]. Praha: České vysoké učení technické v Praze.

VRÁNA K., DAVID V., DOČKAL M., DOSTÁL T., KOUDELKA P., et al., 2009: Optimalizace stavu vodnich ekosystémù v povodi Robečského potoka II. [Optimalisation of water ecosystems stability in Robecsky stream, technical study]. Praha: České vysoké učení technické v Praze, $1,149$.

VAN ROMPAEY A., VERSTRAETEN G., VAN OOST K., GOVERS G., POESEN J., 2001: Modelling mean annual sediment yield using a distributed approach. Earth Surface Processes and Landforms 26 (11), 1221-1236.

VERSTRAETEN G., VAN OOST K., VAN ROMPAEY A., POESEN J., GOVERS G., 2002: Evaluating an integrated approach to catchment management to reduce soil loss and sediment pollution through modelling. Soil Use and Management, 18, 386-394.

WISCHMEIERW.H., SMITH D.D., 1978: Predicting rainfall erosion losses - A Guide to Conservation Planning. Agr. Handbook No 537, US Dept.of Agriculture, Washington.

Streszczenie: Transport sedymentu i jakość wody w Jeziorze Mahovo (Republika Czeska). Położone w północnych Czechach Jezioro Máchovo jest zbiornikiem dla celów rekreacyjnych zbudowanym w XIV wieku przez czeskiego króla Karola IV. Jego zlewnia o powierzchni $100 \mathrm{~km}^{2}$ jest w 25\% intensywnie użytkowana rolniczo, a pozostały zalesiony obszar podlega ochronie. Jakość wody i eutrofizacja wód jeziora oraz towarzyszących mu silnie zamulonych stawów stanowi poważny problem ekologiczny. Celem badań było określenie punktowych i powierzchniowych źródeł dostawy składników pokarmowych i rozwiązanie tego problemu.

Do oceny dostawy sedymentu zastosowano WaTEM/SEDEM model. Została zaproponowana przeciwpowodziowa i przeciwerozyjna ochrona gleby przed erozją oraz gospodarka ściekami w obrębie zlewni. Działania te powinny doprowadzić do polepszenia jakości wody.

\section{MS. received April 2010}

Authors' address:

Department of Irrigation

Drainage and Landscape Engineering

Faculty of Civil Engineering

Czech Technical University in Prague

e-mail:josef.krasa@fsv.cvut.cz 